\title{
The Fight Against Terrorism - Some Observations and Questions
}

\section{Hans-Jürgen Hellwig}

(C) ERA 2011

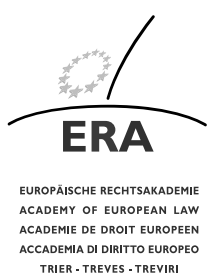

Abstract This article deals with the eternal challenge for a democratic society to find the right balance between security and liberty, and the specific challenge which this means for the legal profession, in the light of recent measures taken to combat terrorism. The author criticises the one-sided focus on public security in the public debate and calls not only for a stronger respect for individual rights but also for a better analysis and combat of the roots of terrorism.

Keywords Terrorism $\cdot$ Security $\cdot$ Freedom $\cdot$ Individual rights $\cdot$ Lawyers $\cdot$ Financial transactions $\cdot$ Reporting

\section{Limiting Individual and Professional Rights in Response to Terrorism}

No other phenomenon has had a greater impact on the life of people in the Western World since the end of World War II than terrorism. The date September 11, 2001 when the World Trade Center in New York was destroyed by air planes that had been captured by terrorists, marks a turning point in history, with the bombings of Madrid, London and Stockholm, to mention only the most important ones in Europe, making it clear that September 11, 2001 was not a onetime event but the beginning of a series of terrorist bombings. Western states adopted one law after the other in order to increase public security. Places, streets, buildings - more or less all public areas - are video supervised. Air passenger data, telecommunication connection data and other private data are stored and passed on. Private homes are secretly eavestapped, and grid searches are made without concrete suspicion in order to find individuals

H.-J. Hellwig Prof. ( $₫)$

Hengeler Müller Rechtsanwälte, Frankfurt am Main, Germany

e-mail: hans-juergen.hellwig@hengeler.com 
that could be possible suspects - first the search, then the suspicion. Most people are not aware of what is going on. We do realise only certain measures such as security controls at airports and railroad stations, at the entrances to buildings etc.

The new laws so adopted do not only have an impact on all citizens at large, they also specifically concern the activities of lawyers. The obligation to report suspicious transactions to which financial institutions had been subjected in 1991 in order to fight organised crime, was extended in late 2001 to lawyers and members of other professions who enjoy a particular protection of the confidence given to them by clients. Some states have used a very broad brush when defining those crimes that can trigger the reporting obligation. This holds true in particular for England which has included in the definition all forms of violation of criminal law, including tax violations in England and abroad. As a result English solicitors every year have made several thousands of reports on suspicious transactions of clients simply because they wanted to protect themselves against criminal prosecution for violation of the reporting obligation - what a perversion of a profession to which clients have particular confidence! In late 2005 the purpose of the reporting obligation regarding suspicious transactions was extended so as to include the fight against terrorism, namely its financing.

A series of decisions in 2007 and 2008 by the European Court of Justice, the Constitutional Court of Belgium and the Conseil d'Etat of France has made it clear that a lawyer, because of his position in the system of administration of justice, when representing a client in court or advising a client outside the court room, may, for reasons of Community law, of the European Human Rights Convention and of national constitutional law, may be subjected to a reporting obligation with regard to suspicious transactions only if he positively knows (and not merely suspects or should suspect) that the client intends to whitewash money or to finance terrorism. Two decisions of the German Constitutional Court, the highest court in the country, of 2004 and 2005 go into the same direction when holding that a criminal defence lawyer commits the act of money laundering through acceptance of the fee payment only when he positively knows that the money is "dirty" - slight or even gross negligence in not knowing is not sufficient. These two decisions are in line with a previous decision of 1979 by the German Supreme Court. In reaction to the terrorist activities of Rote Armee Fraktion (RAF) the German legislator in 1973 had made it a crime to support criminal or terroristic groupings. The criminal defence lawyer of a suspected RAF member had received from the court copies from the court's file which the lawyer passed on to his client. The lawyer was sentenced to jail for support of a terrorist grouping. The Supreme Court acquitted the lawyer, arguing that he had a statutory obligation to inform his client; the risk that the client would abuse such information, has to be accepted; a lawyer commits the criminal act of support of a terrorist grouping only if he positively knows that his client will abuse the information because in such a case the lawyer "in the robe of justice in reality serves injustice and crime". All these decisions ensure that a lawyer may act also in cases of doubt whatever the doubt may relate to, be it questions of fact, be it questions of law, be it the intentions of the client. The lawyer is only prohibited to act against his better positive knowledge - then the lawyer abuses his position in the system of administration of justice in order to serve injustice and crime. 
Also other laws adopted after 2001 that concern all citizens and not specifically lawyers, were declared unconstitutional by the German Constitutional Court in a long line of decisions beginning 2004. Similar court decisions are to be found in other countries in Europe.

Before the background of all these court decisions, many will be inclined to say that the world is in order again. Wrong! There are many problems of principle hidden behind these developments.

\section{Sacrificing Individual Liberties on the Altar of Public Security?}

One such problem is the basic understanding of the relationship between security and liberty. The official reasons when the German government after September 11, 2001 introduced its so-called Legislative Packages on Security, had 37 times the word "security" and not a single time the term "individual rights and liberties"! Former EU Commissioner Frits Bolkestein early 2002 told the Council of the Bars and Law Societies of Europe (CCBE) that the new risks for our democratic states make it imperative "to redefine individual fundamental rights". Lord Peter Goldsmith, then Her Majesty's Attorney General, in November 2005 in a speech to the CCBE entitled "Balancing Security and Fundamental Rights" said verbatim: "Fundamental Rights must be protected if we are to preserve our democracies. But given the current threat to our national security, we must be flexible about how we achieve this. The fact that the balance between security and fundamental rights has traditionally been struck in one way, does not mean that there are not other equally valid approaches." Those present wondered whether Bolkestein and Lord Goldsmith had not read "1984" by Orwell.

To be fair to Bolkestein and Lord Goldsmith: Both have openly addressed the problem. The German Federal Government had not done so when introducing the Legislative Packages on Security after September 11, 2001. This is why Jutta Limbach, in her keynote speech at the Deutsche Anwaltstag (Annual Meeting of the German Bar Association) of 2002, her first speech after she retired as President of the Constitutional Court, asked the question "Is collective security the enemy of individual freedoms and liberties?". Her answer was that there is no clear priority for either of them; they are two competing principles that must be reconciled from case to case. Mrs. Limbach defined three questions that must be addressed in this context, namely first, whether the proposed anti-terrorist measures are suitable to successfully combat terrorism; second, whether the loss of freedom and liberties resulting therefrom is proportionate; and lastly, whether the proposed measures lead to undesirable collateral consequences. With that in mind one wonders even more why the German government did not mention the aspect of individual liberties and fundamental rights at all, with the consequence that they were completely eliminated from the process of democratic discussion among politicians and with the people.

Another problem, or rather an entire group of problems, concerns the principle of separation of powers. It is, of course, true that the hour of danger is always the hour of the executive branch. However, what do we think of a legislative branch that in such a case limits itself to simply signing off on the measures proposed by the 
executive branch, without any evaluation of its own? Also concerned is the allocation of functions within the executive branch. Would it really be a good idea to give up the strict separation between secret services on the one hand and police and criminal prosecution on the other hand?

Thirdly, it is quite conceivable if not likely that the development presently under way will lead to a new concept of public security in which criminal law and police law are merged into one law of public security which has the primary purpose of preventing and combating risks for security. Such law of public security would no longer require a concrete measure constituting a criminal act (or a sufficient suspicion thereof) in order to become operative. It would rather be applicable already if there is merely a general risk situation, i.e. the possibility that any individual could commit such act. Because basically any individual could commit any kind of act, such mere general possibility - well below the level of concrete suspicion in a concrete case would be sufficient to restrict individual rights and liberties. Such an arena of public security would leave no room for the presumption of innocence of the individual public security would be the skeleton key with which the executive branch of government could open up the security lock that protects individual fundamental rights. Would that be a desirable development?

A fourth problem to pay attention to is how the general public has reacted to the developments after September 11, 2001. Of course, since about 2005 some media in Germany (and at about the same time in other countries) have recognised this issue and have begun to openly speak of the danger of a prevention and control state. However, more important from the viewpoint of democracy at large is the question how the general public reacted. With a few exceptions only, the general public did not discuss, or object to, the legislative developments after September 11, 2001. The public did not realise that it is dangerous if politicians focus exclusively on security without making transparent and balancing out, the effects on individual liberties total security is impossible whereas the total supervision and control state is possible. Therefore it was a saddening experience to see how an important achievement of the era of enlightenment and a characteristic of democratic societies, namely the awareness of the value of liberties of the individual, was sacrificed by politicians and the people - in Germany and elsewhere - on the altar of security without the dimension of what was happening becoming transparent. This observation should not be interpreted as an agreement against the priority of public security in a given specific context. It is meant to address the fact that the individual liberties were being completely left out of consideration in the political discussion and decision-making process.

The passive and silent attitude of the public at large is even more surprising as far as Germany is concerned, when one remembers that tens of thousands of citizens were on the streets in Germany when the so-called Emergency Laws to combat the terrorist activities of RAF were adopted way back in 1973. What is different now, after September 11, 2001? Maybe the answer is as follows. The first generations after World War II in the Western countries were deeply aware of the value of individual liberties and of rule of law principles - no wonder after the experience with the totalitarian NS system. Over time this appreciation became weaker. However, as long as the free democratic system of the West and the totalitarian communist system of the 
East opposed each other, nobody in the West questioned the value of individual liberties and of the rule of law - they were an important and maybe even a constitutive element of distinction when comparing the West with the totalitarian systems on the other side of the Iron Curtain. Thus, individual liberties and the rule of law principle for many had their value not so much in themselves but rather from the competition between the political systems of the West and of the East. This has fundamentally changed when the Cold War came to an end and the Iron Curtain fell. Ever since, individual liberties and the rule of law no longer have a per se-value, the presumption of value that followed from the difference and competition between the two political systems has disappeared. Then came September 11, 2001, and with it another change in the appreciation of values. Public security gained an unprecedented importance. For many, politicians and citizens alike, it went without saying that public security the value of which one had just realised when watching on television how the towers of the World Trade Center came down, had absolute priority. The few defenders of individual liberties and rule of law principles were preachers in the desert who had no chance against the many apostles of public security.

Also of relevance in this context is possibly the ever growing commercialisation of our entire life which has been taking place in particular in the last decade and which is closely connected with the phenomenon of globalisation. Should indeed there be a connection between increasing commercialisation and decreasing appreciation of the value of individual rights and rule of law principles then we would be paying a high price for economic success.

In the context of freedom and security Benjamin Franklin is often quoted as having said that he who sacrifices his freedom for the sake of security will in the end lose both of them. A similar citation to be found in an anonymous political pamphlet of 1759 is even more drastic - it goes as follows: "Those who would give up essential liberty to purchase a little temporary safety, deserve neither liberty nor safety."

All of this shows how important it is to counteract the one-sidedness of public discussion. The American Bar Association, in response to the security measures introduced in the USA after September 11, 2001 is sending lawyers and judges into schools and colleges to explain the great importance of individual liberties and of rule of law principles for life in a free democracy. Would this not be a good example to follow in Europe?

We need a better awareness, however, not only as regards the relationship between individual liberties and public security. There is a similar relationship of tension between individual liberties and society. It may well be that we in the West in the recent past have permitted the pendulum to swing too far into the direction of individual liberties, thereby eliminating many limitations that are immanent in such liberties as result of the fact that every individual is part of society. Observers in other parts of the world have questioned, or are even detesting, this "hyper-individualisation" of our liberties. Not only terrorist attacks from the outside but also internal erosion can be a danger for a free society.

A new awareness of the value of individual rights and rule of law principles, reflected in active measures and not just in Sunday speeches, would be important for Europe also with a view to other countries. Many observers in other continents (as is evidenced by experience in the International Bar Association and the Union In- 
ternationale des Avocats) fail to understand that Western democracies insist on fundamental rights and rule of law principles in other countries, however, are readily sacrificing them at home in favour of public security. Quite often the question is being asked whether this contradictory position does not prove that the West instrumentalises such fundamental rights and rule of law principles for its own political and economic purposes.

\section{Tackling the Roots of Terrorism}

A few observers hold the view that the terrorist attacks on Western countries not merely reflect a "Clash of Civilisations" (Huntington) but rather constitute an undeclared war between the Islamistic parts of Islam and the Christian world. This leads to the question which is probably most important and which is not being asked in the general public at all: What are the reasons for these terrorist attacks?

As early as spring 2002 the question was asked in the USA how one could sensibly deal with the phenomenon of terrorism without first having analysed its reasons. A study by Harvard University of May 2002 came to the conclusion that the readiness for terrorist activities follows neither from poverty nor illiteracy but is rather the reaction to humiliation. Islamic societies once were among the economic and scientific leaders of the world. Today it is the West that is hugely superior on more or less all fronts. Superiority is perceived as humiliation when accompanied by arrogant behaviour. Abu Ghraib and Guantanamo have been taken as evidence, and have become symbols, of that humiliation.

There is another source that fuels terrorism, and that is the hurting of somebody else's religious feelings and convictions. This is a lesson to be learnt from the reaction of the Islamic World to the Copenhagen cartoons of Mohammed. An Arabian lawyer with long working experience in the West with whom I discussed the matter, made the clear cut-point: "You Westerners readily give up your liberties when your security is at stake but you insist on them when you hurt the religious feelings of others". The legal profession is familiar with conflicts of laws, and we have special conflict rules to deal with them. What is missing are rules on how to deal with conflicts of religion and culture. To address this issue and to try to find solutions in my mind is a huge task especially for us lawyers.

When discussing the phenomenon of terrorism with colleagues from Islamic countries we are often being confronted with the unresolved conflict between Israel and the Palestinians, and the question is being asked why the West does not get Israel to stop its repeated violations of UN-Resolutions while the same West forces other countries to comply with UN-Resolutions. This question and the reproach inherent therein which is sometimes even voiced expressis verbis, apparently is part of the background why Islamistic organisations in other countries exercise solidarity with the Palestinians and engage in terrorist attacks on certain countries of the West.

It was completely counterproductive in this context when US-President George W. Bush used the word "crusade" in connection with the war against Iraq and labelled Iraq, Iran and North Korea as "Axis of Evil", with the term "evil" in English and American having a religious meaning in the direction of devil. Many people in the Islamic World inevitably associated these words with the crusades of Christian Europe 
against the Islamic world in the middle ages. As a consequence it was extremely difficult for moderate Muslims to prevent aggressive Islamic groups to declare "djihad" to the USA and the entire West. The wave of killings and expulsion of Christians in parts of the Islamic World that we experience at the moment would probably be inconceivable without the aforesaid remarks by George W. Bush - many Muslims suspect the Christians in their countries to pursue political aims that reflect the spirit of George W. Bush.

The aforesaid remarks do not give much comfort. It is important to deal with the question how to prevent terrorist activities. However that alone is not sufficient. When thinking matters through it is more important to deal with the question why we have these terrorist activities and what we can do to change the attitude and thinking which is the fertile soil from which such terrorist activities grow. Are we prepared to deal with that question? Are we capable for the necessary self-criticism? 